\title{
Gender and Health in Spanish Nurses ${ }^{1}$
}

\author{
Virginia Dresch², María del Pilar Sánchez-López ${ }^{3}$, Ana Isabel Saavedra ${ }^{4}$ \\ ${ }^{2}$ Universidade Federal Fluminense, Niterói-RJ, Brazil \\ ${ }^{3}$ Universidad Complutense de Madrid, Madrid, Spain \\ ${ }^{4}$ Hospital Universitario de Getafe, Getafe, Spain
}

\begin{abstract}
: gender exercises a powerful effect on determining health status: it may limit different rates of exposure to certain risks, different patterns in the quest for treatment or differential impacts of the social economic determinants of health. The object of this study has been to discover the relationships between gender and health in a special group of the Spanish population, male/female nurses. Spanish male $(n=98)$ and female $(n=98)$ nurses completed measures of gender norms, and health behavior variables. The analysis of correlations between health variables and gender norms indicates that registering a higher score in gender norms correlates with lower scores in physical and mental health and lifestyles. The logistical regression equations (self-perceived health, mental health and the number of illnesses suffered) identify differences between male and female nurses, with the only common variable being the level of perceived stress.
\end{abstract}

Keywords: gender, health, nursing

\section{Gênero e Saúde em Enfermeiras Espanholas}

Resumo: O gênero exerce um efeito poderoso na determinação do estado de saúde. Ele pode limitar diferentes níveis de exposição a certos riscos, diferentes padrões na busca por tratamento ou diferentes impactos de determinantes socioeconômicos na saúde. Este estudo teve por objetivo descobrir as relações entre gênero e saúde em um grupo especial da população espanhola, enfermeiros e enfermeiras. Enfermeiros $(n=98)$ e enfermeiras $(n=98)$ completaram medidas de normas de gênero e comportamentos de saúde. A análise das correlações entre variáveis de saúde e normas de gênero indicaram que um alto escore nas normas de gênero se correlaciona com baixos escores de saúde física/mental e estilos de vida. As equações de regressão logística (saúde auto percebida, saúde mental e número de dolências) identificaram diferenças entre enfermeiros e enfermeiras; estresse percebido foi a única variável em comum.

Palavras-chave: gênero, saúde, enfermagem

\section{Género y Salud en Enfermeras Españolas}

Resumen: el género ejerce un efecto poderoso en la determinación del estado de salud y puede limitar diferentes niveles de exposición a ciertos riesgos, diferentes patrones en la búsqueda por tratamiento o diferentes impactos de determinantes socioeconómicos en la salud. El objetivo de este estudio fue descubrir las relaciones entre género y salud en un grupo especial de la población española, enfermeros y enfermeras. Enfermeros $(n=98)$ y enfermeras $(n=98)$ completaron medidas de normas de género y comportamientos de salud. El análisis de las correlaciones entre variables de salud y de género indicaron que un alto escore en las normas de género se correlaciona con bajos escores de salud física/mental y estilos de vida. Las ecuaciones de regresión logística (salud autopercibida, salud mental y número de dolencias) identificaron diferencias entre enfermeros y enfermeras; estrés percibido ha sido la única variable en común.

Palabras clave: género, salud, enfermería

This work starts, in the first place, from the verification of the relationships between sex, gender and health (World Health Organization [WHO], 2007). Sex has a profound

\footnotetext{
${ }^{1}$ Article derived from the doctoral thesis of the third author under the supervision of the first and second authors, defended in 2013, in the Graduate Program Mujeres y Salud of the Universidad Complutense de Madrid. We thank the University Hospital of Getafe, Spain, for its involvement in the Project.

Correspondence address: Virginia Dresch. Universidade Federal Fluminense. Departamento de Psicologia, Campus do Gragoatá, Bloco N, Niterói-RJ, Brazil. CEP 24.210-201. E-mail: virginiadresch@id.uff.br
}

impact on determining the status of health: in fact, it may establish the differential propensity to certain states of health or illness, different risk factors or different treatment needs. Similarly, gender also exercises a powerful effect on determining health status: it may limit different rates of exposure to certain risks, different patterns in the quest for treatment or differential impacts of the social and economic determinants of health. If we do not differentiate between the sexes when we research their relationships with health this may lead to the masking of the influence of gender on health. 
So, our second starting point is based on the need to bear gender in mind and make it operative in one way or another. Gender is defined as the result of a process of evolution by which expectations and norms are internalized. From the seventies onwards, empirical works dealing with the meaning of femininity and masculinity began to take on importance (Auster \& Ohm, 2000), socially constructed concepts that evolved historically. These early approaches were not very suitable since they used global indexes and did not consider the multidimensional nature that was being displayed in the most up-to-date research works on the topic. Based on these critiques, such authors as Mahalik (Mahalik et al., 2003, 2005) introduced the concept of "social norm" as a basis for constructing tools for gender evaluation. Social norms are rules and standards understood and shared by the members of a group and they guide their social behavior just as strongly as laws do. In this manner, femininity and masculinity are a heterogeneous set of social norms regarding attitudes, beliefs and relationships which appear reasonable for men and women in each culture.

Our third starting point is the findings of the ever-increasing number of research papers which discover a relationship between gender and health. For example, some authors have shown that traditional masculinity is associated with behavior containing a coronary risk, better mental health, less frequent use of mental health services or greater self-esteem and lower levels of anxiety and depression (Addis \& Mahalik, 2003; Limiñana-Gras, Sánchez-López, Saavedra-San Román, \& Corbalán-Berná, 2013; Mahalik, Burns, \& Syzdek, 2007; Sánchez-López, Cuellar-Flores, \& Dresch, 2012).

Regarding hospital male/female nurses, the case with which we are concerned, we may find very heterogeneous results on health, for women and men in the international bibliography (Fisher, 2011; Lee, Tsai, Tsai, \& Lee, 2011).

Particularly outstanding is the study by Talley, Thomas, and Brown (2009), which compares male nurses from England, USA and Canada with their respective general populations. Significant differences are found only in the female sample of nurses from the age of 35-44 years where the lowest scores are found in both physical and psychological health and there is an increase in the Body Mass Index (BMI). The authors point out as significant risk factors for these ages caring for small children, the unwillingness of the spouse to share responsibilities and not enough time to look after their own physical and mental health.

An important aspect to be considered is the incidence of night work and its negative effects upon physical and psychological health, among which the greatest risk is the appearance of breast, endometrial or colon cancer, and suffering digestive or cardiovascular diseases, of which there is a large number in the bibliography (Izú, Cortez, Valente, \& Silvino, 2011). Other studies point out the relationship between working nights and stress-generating factors, earlier appearance of syndromes such as burnout and disturbed sleep patterns (ranging from insomnia to difficulty in falling asleep and getting enough sleep) (Bonet-Porqueras et al., 2009), as well as a greater proportion of alimentary problems, higher cholesterol levels in the blood, greater incidence of varicose veins and lower scores in the social support dimension.

The group of hospital nurses, male and female, is particularly attractive for our aims for two reasons: (1) because caring is thought to be "naturally" feminine and, as is expected of a profession consisting of looking after people, it is a job largely taken on by women, and this indeed occurs on a global scale (Instituto Nacional de Estadística [INE], 2012). In this profession, men are an "anomaly" because they choose a job with lower status and linked to women (Battice, 2010). Therefore, within the nursing profession, two different groups coexist that can show the mechanisms relating gender with health: in one case, that of women, in an occupation in which they are the majority; in the other, that of men, where they are a minority. And (2) As for relationships between gender norms and health, the bibliography points out that male nurses conform less to masculine norms (Limiñana-Gras et al., 2013). However, data for women nurses are not clear (Loughrey, 2008) and to verify how this affects health, from the relationships mentioned in the cited bibliography would be a significant contribution from this work.

Based on all of the above items, the aims of this study are: (1) to ascertain whether male nurses conform less to male norms and whether female nurses conform more to female norms; (2) to bear in mind the previous pattern to discover, in the case of male/female nurses, whether the relationships between sex, gender and health are the same as in the general population. That is, whether differences in conformity to gender norms in male/female nurses compared to the population (lower conformity to male norms in male nurses and greater conformity with the female norms in the case of female nurses) interfere on the health pattern in male and female nurses (gender differences).

Based on the above-mentioned aims, we propose the follows hypothesis:

(1) Hypothesis 1: With equal sociodemographic and employment variables and compared to the general population, male nurses show lower levels of conforming to male norms and female nurses conform more to female norms.

(2) Hypothesis 2: Despite lower conformity to masculine norms in men and higher conformity to female ones in women, the detailed analysis of relationships between gender and health show clearly a traditionally masculine pattern for men and a traditionally feminine pattern for women.

(3) Hypothesis 3: The independent variables which explain health indexes (dependent variables) will be different depending on whether they are male or female nurses.

\section{Method}

\section{Participants}

As we propose to compare health behavior of male and female nurses and, given the shortage of male nurses, which may skew the characteristics, we have taken determined 
care in choosing and matching the group of male and female participants.

The study was carried out with 98 male nurses and 98 female nurses, all of them Spanish, working in one of the tertiary university hospitals of the Community of Madrid, representative of the hospitals in the network of the Spanish National Health system.

From a total number of 103 male nurses in the hospital, 98 volunteered to participate in the study. Of the total number of female hospital nurses (588), 98 were selected, as they met the same sociodemographic criteria (age, marital status, number of children and number of dependents they cared for), and with the same work shift and service in the hospital as their male colleagues.

Nurses' average age was 32.45 years $(S D=16.84)$, ranging between 20 and 56 . The males' average age was 32.29 years $(S D=8.64)$ and females' was $32.60(S D=8.20)$ ranging between 22 and 56 years for females and 20 and 56 for males. The males had worked for an average of 101.92 months $(S D=99.43)$ and the females 114.92 months $(S D=92.83$.).

\section{Instruments}

Sociodemographic variables were assessed with a questionnaire. We considered age, marital status, having children, having elderly people to care for, the service where they worked, whether they were on night shift, and whether they received any help with housework. Selected health variables are the ones most frequently used in research on health, sex and gender, which have been grouped together for practical purposes in three categories: 1 - Physical health; Self-perceived health, Pains, Use of medicine and visits to the doctor. 2 - Lifestyles, (Tobacco consumption, Alcohol consumption, Sleep problems and Physical activity). 3 - Mental health measured by the Spanish GHQ-12 and Work Stress. We used the items from the National Health Survey to measure Physical Health and Lifestyles.

For the reasons expressed above, the instrument chosen for gender measurement was the Conformity to Masculine Norms Inventory (CMNI) (Mahalik et al., 2003) and the Conformity to Feminine Norms Inventory (CFNI) (Mahalik et al., 2005), adapted for the Spanish population (Cuéllar-Flores, Sánchez-López, \& Dresch, 2011; Sánchez-López, CuellarFlores, Dresch, \& Aparicio García, 2009) and they have been shown to have satisfactory psychometric properties. The statements of the CMNI are designed to measure attitudes, beliefs and behaviors that reflect conformity or nonconformity to 11 subscales associated with masculine gender roles. The
CFNI has 8 subscales of feminine norms that measure various attitudes, beliefs and behaviors associated with feminine gender roles, both traditional and non-traditional.

\section{Procedure}

Data collection. A personalized interview was held with each of the hospital male nurses, and they were given a detailed report of the research. All those concerned who had volunteered their participation in the study, 98 male nurses, were given a questionnaire and the relevant consent form. We also guaranteed the anonymity of their data.

Similarly, a personalized interview was held with each of the 588 female nurses from the hospital, and from them, the same number of participants was selected, as the one obtained from the male sample (98). They also met the same criteria in sociodemographic variables and work contract characteristics as the male nurses. Once selected, the 98 female nurses (at random, among those meeting the requirements), were given the same questionnaire and relevant consent form, guaranteeing the anonymity of the data. All information is stored by the researcher in her home address.

Data analysis. Data analysis consisted of a comparison of averages and regression logistic analysis.

\section{Ethical Considerations}

The study was approved by the Ethical Committee of the Hospital Universitario de Getafe at May 26, 2010.

\section{Results}

No significant differences between male and female nurses were found in the following sociodemographic variables: age, number of months in the University Nursing Diploma (DUE), number of children, age of first child, age of second child, number of dependents, age of first dependent, age of second dependent, marital status, night shift and paid help. Males and females only differed significantly in help with housework $\left(\chi^{2}=5.84 ; p<.05\right)$, in which $41.8 \%$ of women versus $25.5 \%$ of men received this kind of support at home.

Regarding gender, equal in sociodemographic and work variables, male nurses conform less to masculine norms and female nurses conform more to the feminine ones, compared to the general Spanish population. The corresponding data are shown in Table 1. 
Table 1

Descriptive CMNI and CFNI and Comparison of Averages with Spanish Population

\begin{tabular}{|c|c|c|c|c|c|c|c|c|}
\hline \multirow{2}{*}{ CMNI Scales } & \multicolumn{3}{|c|}{ Men } & \multicolumn{3}{|c|}{ Men Spanish population ${ }^{\mathrm{a}}$} & \multirow[b]{2}{*}{$t(97)$} & \multirow[b]{2}{*}{$d$} \\
\hline & $n$ & $M$ & $S D$ & $n$ & $M$ & $S D$ & & \\
\hline 1. Winning & 98 & 12.97 & 3.67 & 727 & 13.59 & 4.08 & $-1.67 \mathrm{~ns}$ & - \\
\hline 2. Emotional Control & 98 & 14.40 & 4.51 & 727 & 14.65 & 4.47 & $-.55 \mathrm{~ns}$ & - \\
\hline 3. Risk-Taking & 98 & 13.77 & 3.56 & 727 & 14.76 & 3.61 & $-2.77 * *$ & -.27 (low) \\
\hline 4. Violence & 98 & 7.74 & 3.80 & 727 & 9.96 & 4.14 & $-5.77 * * *$ & $-.54(\mathrm{mod})$ \\
\hline 5. Power over women & 98 & 6.33 & 3.02 & 727 & 8.86 & 4.59 & $-8.3 * * *$ & $-.57(\mathrm{mod})$ \\
\hline 6. Dominant & 98 & 4.71 & 1.74 & 727 & 5.33 & 2.01 & $-3.51 * *$ & $-.31(\mathrm{mod})$ \\
\hline 7. Playboy & 98 & 13.29 & 4.58 & 727 & 14.19 & 5.46 & $-1.95^{*}$ & -.17 (low) \\
\hline 8. Self Reliance & 98 & 4.79 & 2.62 & 727 & 6.68 & 2.60 & $-7.15 * * *$ & -.73 (high) \\
\hline 9. Primacy of Work & 98 & 8.35 & 2.92 & 727 & 9.19 & 3.50 & $-2.86 * *$ & -.24 (low) \\
\hline 10. Disdain for Homosexuals & 98 & 10.26 & 5.16 & 727 & 12.27 & 5.08 & $-3.87 * * *$ & $-.40(\mathrm{mod})$ \\
\hline 11. Pursuit of Status & 98 & 9.88 & 2.28 & 727 & 9.60 & 2.64 & $1.20 \mathrm{~ns}$ & - \\
\hline Total CMNI & 98 & 106.47 & 19.54 & 727 & 119.13 & 22.64 & $-6.41 * * *$ & $-.57(\mathrm{mod})$ \\
\hline \multirow{2}{*}{ CFNI Scales } & \multicolumn{3}{|c|}{ Women } & \multicolumn{3}{|c|}{ Women Spanish population ${ }^{\mathrm{b}}$} & & \\
\hline & $n$ & $M$ & $S D$ & $n$ & $M$ & $S D$ & $t(97)$ & $d$ \\
\hline 1. Relationships & 98 & 36.85 & 4.92 & 780 & 36.15 & 6.30 & $1.4 \mathrm{~ns}$ & - \\
\hline 2. Thinness & 98 & 17.83 & 6.32 & 780 & 15.18 & 5.44 & $4.14 * * *$ & $.48(\bmod )$ \\
\hline 3. Modesty & 98 & 13.79 & 3.07 & 780 & 13.16 & 3.38 & $2.01 *$ & .19 (low) \\
\hline 4. Domestic & 98 & 17.11 & 2.94 & 780 & 16.05 & 4.01 & $3.58 * *$ & .27 (low) \\
\hline 5. Care for children & 98 & 20.22 & 6.88 & 780 & 21.84 & 6.57 & $-2.33^{*}$ & -.25 (low) \\
\hline 6. Romantic & 98 & 14.12 & 3.67 & 780 & 13.72 & 3.48 & $1.08 \mathrm{~ns}$ & - \\
\hline 7. Sexual fidelity & 98 & 16.40 & 4.11 & 780 & 16.03 & 5.45 & $0.89 \mathrm{~ns}$ & - \\
\hline 8. Appearance & 98 & 12.63 & 3.47 & 780 & 11.09 & 3.40 & $4.4^{* * *}$ & $.45(\bmod )$ \\
\hline Total CFNI & 98 & 148.95 & 15.72 & 780 & 143.22 & 20.51 & $3.61 * * *$ & .29 (low) \\
\hline
\end{tabular}

Note. ${ }^{a}$ From Sánchez-López et al. (2009); ${ }^{\circ}$ From Cuéllar-Flores et al., 2011; ${ }^{*} p<.05 ; * * p<.01 ; * * * p<.001$; ns: non-significant.

Regarding hypothesis 1 , as we can see in Table 1, male nurses score significantly lower according to eight of the eleven CMNI scales, and in the total average. Female nurses, unlike the men, obtained significantly higher scores in their conformity to five of the eight CFNI scales, and in total conformity score. Curiously, the only scale in which they scored significantly lower in conformity than women in the general population was on a scale relating to care: Care for children.
Regarding hypothesis 2, the detailed analysis of relationships between gender and health show a clearly masculine pattern for men and a clearly feminine one for women. To the male nurses, is particularly significant the consistency with the traditional role on the CMNI-2 Emotional control scale and obtain better scores on selfperceived health $(r=.30 ; p<.01)$ and make fewer visits to the doctor $(r=-.20 ; p<.05)$. There is a direct relationship between the CMNI-3 Risky behavior scale and more frequent 
visits to the doctor $(r=.25 ; p<.05)$; the CMNI-4 Violence scale has an inverse relationship with consumption of medicines $(r=-.20 ; p<.05)$ and a direct one with frequency of alcohol consumption $(r=.22 ; p<.05)$. Those male nurses scoring highly on the CMNI-6 Dominant scale visit the doctor less often $(r=-.20 ; p<.05)$ and are less satisfied in their job $(r=-.24 ; p<.05)$. Male nurses with high scores on the CMNI-7 Playboy scale are more frequent alcohol consumers $(r=.32 ; p<.01)$; showing consistency in the traditional male role, the scale CMNI-10 Disdain for homosexuality is inversely related to the number of health complaints $(r=-.28 ; p<.01)$, and finally, the high score on the CMNI-11 Pursuit of status scale correlates with lower satisfaction with work $(r=-23 ; p<.01)$ and with higher alcohol consumption $(r=.24 ; p<.05)$.

To the female nurses, is noticeable that a high score on the traditional feminine role from the CFNI- Thinness scale is associated with higher alcohol consumption $(r=.20$; $p<.05)$ and greater sleep problems $(r=.25 ; p<.05)$. A direct relationship is noticed between the CFNI-Modesty scale which shows an increase in the frequency of selfperceived poor health $(r=.29 ; p<.01)$ and an inverse one with alcohol consumption $(r=-.23 ; p<.01)$. The $C F N I-$ Child caregiver scale is correlated with a lower tobacco consumption $(r=-.21 ; p<.05)$. Scoring highly on the CFNIBeing romantic in relationships scale has a direct relationship with the frequency of alcohol consumption $(r=.22 ; p<.05)$. Finally, the most statistically significant scale is the CFNIInvest in image or appearance, so that scoring a high mark on this scale is directly related to frequency of alcohol consumption $(r=.28 ; p<.05)$.

To complete the statistical analyses and compare hypothesis 3 multivariate regression analyses have been used. In the initial stage a bivariance was performed between the dependent variables showing the highest significant statistical differences between male and female nurses: (a) self-perceived health (Mann-Whitney $\mathrm{U}=4035$; $\mathrm{N} 1=98 ; \mathrm{N} 2=98 ; p<.05$ ); (b) mental health (Mann-Whitney $\mathrm{U}=3918 ; \mathrm{N} 1=98 ; \mathrm{N} 2=98 ; p<.05)$; and (c) number of health problems (Mann-Whitney $\mathrm{U}=3357$; $\mathrm{N} 1=98$; $\mathrm{N} 2=98 ; p<.001)$. With these three dependent variables individually for each of them and for each gender, bivariant analyses were made and it was proposed to analyze what is the part of the explained variance of these variables on the basis of the rest of the independent variables studied: (1) Physical health: medicine taken, cortisol levels at 8 and 20 hours and number of visits to the doctor (family doctor and specialist doctors); (2) Mental health: work induced stress and job satisfaction; (3) Lifestyles, tobacco consumption, frequency of alcohol consumption, sleep patterns, physical exercise, food, diets followed, being a day or night person.

All these analyses, the variables of which obtain a significance level of $p<.05$, will enter the multivariate logistical regression model with a (stepwise) method for the construction of the regression model (See Tables 2 and 3).
Table 2

Regression Logistic Analysis to Female Nurses

I.C. $95 \%$ to O.R.

\begin{tabular}{lccccc}
\hline Variables & B & $p$ & O.R. & Lower & Higher \\
\hline $\begin{array}{l}\text { Self-perceived health } \\
\text { (Step 2) }\end{array}$ & & & & & \\
Mental health & 1.445 & .010 & 4.240 & 1.405 & 12.795 \\
Health complaints & 2.460 & .021 & 11.703 & 1.450 & 94.490 \\
$\begin{array}{l}\text { Mental health } \\
\text { (Step 3) }\end{array}$ & & & & & \\
$\begin{array}{l}\text { Night shift stress } \\
\begin{array}{l}\text { Stress } \\
\text { Hours of daily sleep }\end{array}\end{array}$ & 1.564 & .062 & 4.780 & .922 & 24.786 \\
$\begin{array}{l}\text { Sleep Problems } \\
\text { (Step 1) }\end{array}$ & .798 & .007 & 2.220 & 1.248 & 3.950 \\
$\begin{array}{l}\text { Self-perceived poor } \\
\text { health }\end{array}$ & 2.506 & .017 & 12.255 & 1.557 & 96.460 \\
\hline
\end{tabular}

Table 3

Regression Logistic Analysis to Male Nurses

I.C. $95 \%$ to O.R.

\begin{tabular}{lccccc}
\hline Variables & $\mathrm{B}$ & $p$ & O.R. & Lower & Higher \\
\hline $\begin{array}{l}\text { Self-perceived health } \\
\text { (Step 2) }\end{array}$ & & & & & \\
CMNI2 Emotional & -.37 & .007 & .69 & .532 & .904 \\
Control & & & & & \\
Hours of daily sleep & 2.78 & .041 & 16.13 & 1.128 & 230.676 \\
$\begin{array}{l}\text { Mental health } \\
\text { (Step 4) }\end{array}$ & & & & & \\
Age & & & & & \\
$\begin{array}{l}\text { Self-perceived poor } \\
\text { health }\end{array}$ & 2.428 & .038 & 11.338 & 1.139 & 112.857 \\
Stress & .021 & .895 & .814 & .983 \\
Job Satisfaction & .648 & .021 & 1.911 & 1.103 & 3.314 \\
Sleep Problems & -.613 & .005 & .542 & .354 & .829 \\
(Step 4) & & & & & \\
CMNI Total & & & & & \\
CMNI1-Winning &. .042 & .019 & .959 & .926 & .993 \\
Mental health & .332 & .001 & 1.394 & 1.148 & 1.693 \\
Age & 1.607 & .012 & 4.987 & 1.415 & 17.571 \\
\hline & .095 & .004 & 1.100 & 1.030 & 1.174 \\
\hline
\end{tabular}


As we can see in Tables 2 and 3, the only similarity found in the analyses carried out is stress at work, which appears as a predictor of the mental health variable, both for men and female nurses. The regression equations for the three dependent variables (self-perceived health, mental health and number of health problems) are different depending on whether we are dealing with men or women nurses.

Regarding the variable self-perceived health of female nurses, it is shown that having poor mental health leads to a fourfold increase in the likelihood of their having selfperceived health and having medical problems makes self-perceived poor health eleven times more likely. The likelihood of the women in the sample having poor mental health shows a twofold increase if there is an increase in stress-related work and multiplies by six if there is not enough sleep/rest, as well as being multiplied by 5 if the night shift is worked and, in the case of the variable number of health problems, there is a risk of a twelvefold increase if the woman perceives herself as having poor health.

For male nurses increasing the score on the traditional gender CMNI-2 emotional control scale reduces by $30 \%$ the risk of having self-perceived poor health and among those male nurses who do not rest enough there is a 16 fold risk of suffering self-perceived poor health. The mental health variable improves with age, so, for every 10 years of extra age in male nurses, the likelihood of having poor mental health shows a $33 \%$ fall and with self-perceived poor health there is an 11 fold rise in the likelihood of having poor mental health. It is also objectivized that a 1-point increase in levels of work-related stress among male nurses leads to a $46 \%$ reduction in the likelihood of having poor mental health.

Regarding the health problems variable, in male nurses it is calculated that it would fall by $4 \%$ if there were an increase in the findings on the total scale for measuring the acceptance of traditional male norms. However, an increase in the score on the CMNI-1 scale would give rise to a 1.4fold increase in the risk of having health problems, as well as the fact that having poor mental health would increase by a multiple of 5 the likelihood of having health problems and for each 10-year increase in the age of male nurses, the likelihood of suffering physical pains shows a $259 \%$ rise.

\section{Discussion}

The object of this study has been to discover the relationships between gender and health in a special group of the Spanish population, male/female nurses. Firstly, regarding hypothesis 1 , although male and female nurses in our participant groups were equal in sociodemographic variables, they show a differential conformity to the prevailing gender norms in Spanish society. That is, in general, male nurses are less masculine and female nurses more feminine than men and women in the general population. Nevertheless, in the case of women, this does not appear to be confirmed for the childcare norm. This is something that could be discussed in the light of other findings on women's health in this occupational context. They underline the existence of greater role conflicts related to the care of small children and the lack of coresponsibility of their spouses as the main risk factors for their mental and physical health (Talley et al., 2009).

About hypothesis 2, the analysis of the inter-gender relationships (conformity to gender norms) and health highlights a clearly masculine pattern for men and a clearly feminine one for women. Data indicate higher alcohol consumption and greater conformity to masculine norms in male nurses, and lower tobacco consumption and higher conformity to female norms in female nurses. As in previous works (Cuéllar-Flores et al., 2011; Cuéllar-Flores, \& Sánchez-López, 2011; Mahalik et al., 2003), the relationships discovered between gender and health are very moderate but confirm the traditionally male and female habits in health. Moreover, as in those very same previous works, the total measure of conformity to gender shows little relationship with health indexes. This confirms the convenience of a multidimensional scale, such as those used in this paper (CFNI/CMNI) which are geared towards ascertaining what are the dimensions of conformity to gender norms which have a greater relationship to health indexes.

A detailed analysis of the scores in each of the scales reveals a pattern of illness in male nurses which is still masculine despite their lower conformity as a group, to masculine norms, and a clearly feminine illness pattern in female nurses. In fact, in the case of male nurses, conformity to the emotional control norm is related to better self-perceived health and fewer visits to the doctor; violence is related with lower use of medicines and higher use of alcohol. Dominance scale is associated with fewer visits to the doctor and lower work satisfaction: playboy scale goes with higher alcohol consumption; disdain for homosexuality scale with fewer complaints. Finally, the pursuit of status scale is associated with lower work satisfaction and higher alcohol consumption. The relationship between alcohol consumption and traditionally masculine behaviors such as self-control, playboy, or promiscuity and violence have already been confirmed in previous studies (Cuéllar-Flores \& Sanchez López, 2011; Mahalik et al., 2003; Mahalik, Lagan, \& Morrison, 2006; Sánchez-López et al., 2012).

Positive relationships between risk taking and visits to the doctor may perhaps be explained precisely by the higher probability of suffering an accident if more risk is accepted. Also, the relationships between higher assessment of one's social position and lower work satisfaction may be due to the type of work undertaken by these male hospital nurses, a work in which they find few chances of increasing their social prestige. This may also give rise to higher alcohol consumption.

In the case of the women, greater conformity to the care for children norm is related to lower tobacco consumption, and the higher scores on the modesty scale with worse selfperceived health and lower alcohol consumption. These 
characteristics are compatible with a traditional gender pattern, in which the tobacco habit and alcohol consumption are not related to feminine habits.

Similarly, relationships between the importance given to being slim and sleep problems would also be congruent with the feminine health pattern, in which women demonstrate more sleep problems than males, so that the more they cohere with traditional female gender norms the more they demonstrate sleep problems.

However, relationships between alcohol consumption and conformity to some female gender norms would identify a risk pattern for health related to the higher importance of slimness, of romantic relationships and image in this group of women.

In general, these results show the existence of relationships between gender and health in the nursing profession like those identified in other social and occupational contexts (Cuéllar-Flores \& Dresch, 2012; Cuéllar-Flores \& SánchezLópez, 2011; Mahalik et al., 2003, 2007). However, some of these relationships enable us to identify differential health behaviors for men and for women and highlights specific relationship mechanisms between gender and health for men and women in atypical occupational contexts. This has already been demonstrated in some qualitative studies (Simpson, 2009), which describe how a gender imbalance may give rise in the minority to so much pressure and restraint, such as greater visibility and status symbolism. In the case of nursing these mechanisms are related, for women, with practice of a traditionally female activity but in a professional context where they are no longer the center of attention. In the case of the men, it would be related to practicing a traditionally feminine role in an occupational context where women dominate. Here, being in a minority would give rise to pressures to develop role norms related to stereotypes of male gender roles and fear of becoming feminized or stigmatized (Lupton, 2000). Nonetheless, it also appears to endow them with greater insight and possibility of promotion than their female counterparts (Simpson, 2009). This advantage could also partially explain the better health found in male nurses both in comparison with women and compared to men in general, as discovered in other studies (Limiñana-Gras et al., 2013).

The variables obtained from the logistic regression equations which explain part of the variances in self-perceived health, mental health and number of health problems show a difference between men and women. Work-related stress is identified as the common denominator for both sexes.

As can be observed in the section of results for female nurses, having poor mental health increases the likelihood of having self-perceived poor health, and having medical problems produces an 11 fold increase in the risk of having self-perceived poor health.

The relationship between self-perceived poor health and poor mental health has been shown in different researches (Conry et al., 2011; Mao \& Zhao, 2012) and the findings for female nurses coincide with those recorded in the research carried out by Sánchez-López, Aparicio García, and Dresch
(2006), where the conclusion is that physical health in women is closely linked with mental health.

There is copious documentation concerning the deterioration of mental health in women nurses, when there is an increase in work-related stress and especially if there is no adequate provision of rest/sleep, all of which is to be found in studies of female nurses. Such a situation is the result of high levels of stress associated with the profession and difficulties in sleeping due to night shifts, which have a negative effect on nurses' psychological state (Bonet-Porqueras et al., 2009; Deschamps Perdomo, Olivares Román, De la Rosa Zabala, \& Asunsolo del Barco, 2011; Izú et al., 2011; Sindicato de Enfermería [SATSE], 2012).

Data obtained on the relationship between the variable "number of health problems" and the risk of having selfperceived health problem in women in the nursing profession coincide with the relevance in using the scale of selfperceived health as the initial indicator of a person's state of health (Simon, De Boer, Joung, \& Mackenbach, 2005).

For male nurses, increasing the score on the traditional gender CMNI-2 - Emotional Control scale produced a 30\% fall in the risk of having self-perceived poor health, and referring to rest as inadequate increases the risk of having self-perceived poor health; data corroborated in international biography regarding the health of professional male nurses and their problems in being able to rest (Deschamps Perdomo et al., 2011; Izú et al., 2011; SATSE, 2012).

Improvement in the "mental health" variable as the male nurses grow older. corroborates the data obtained in different publications with health workers. The best scores in the GHQ-12 in the samples of over 40 years compared to the younger ones may be due to emotional stability, along with more stability in their work and more trust in their professional knowledge (Al-Dubai \& Rampal, 2010). The relationship between self-perceived poor health and a greater likelihood of having poor mental health has also been corroborated in other studies. This relationship is most significant in women than men, but nonetheless there still exists (Sánchez-López et al., 2006); a reduced likelihood of $46 \%$ when there is a 2-point rise in job satisfaction. This is well attested in research in which the relationship is established between the work environment, the importance of being a provider of resources and mental health in men (Sánchez-López, López-García, Dresch, \& Corbalán, 2008).

Proofs confirm that the greatest acceptance of the traditional masculine role is associated with lower scores when referring to having health problems, as appears with male nurses regarding the increase in the total CMNI score (Mahalik \& Burns, 2011); however, increasing the score in the CMNI1-Winning scale would increase the risk of having health problems. A possible explanation would be based on the specificity of the characteristic problems of the profession itself and the need to work in teams and seek consensus in action taken. In this manner attitudes geared to imposing determined criteria might be related with 
greater health problems (Instituto de Salud Carlos III, 2011; SATSE, 2012).

The increased likelihood of having health problems in the case of male nurses, if the reference is to poor mental health, is documented in the studies of the Spanish male population carried out by Sánchez-López et al. (2008). It can likewise be expected that the likelihood of having physical pains increases with age and this is recorded in studies of demography and health in Spanish men (Sánchez-Herrero Arbide, Sánchez-López, \& Dresch, 2009). In any case it is worth stressing that in female nurses age explains none of the dependent variables analyzed. Alongside other variables related with health in women nurses, the importance of the age variable declines and finally disappears.

To sum up, just as has been found in the case of women in the Spanish population in general, for female nurses the state of their physical health is closely linked with their psychological health and, in turn, the psychological state with variables such as work-related stress and having enough rest. Nevertheless, with male nurses, although there is also a relationship between physical health and mental health, it occurs in a less significant manner than in the women (Sánchez-López et al., 2006) and the latter relationship is modulated by such variables as age, conformity with gender roles, rest and job satisfaction.

This study has some limitations. One of them is the use of self-reported measures to evaluate diseases, which provides the potential for misclassification of these outcomes and for special acceptability bias. Future studies could include objective measures of diseases, in addition to subjective measures to verify whether the subjective and objective measures are correlated (for example, laboratory tests that confirm the diagnosis of diseases, indicators of the immunological system, and other biomarkers).

Another limitation is the generalizability of results like these to other populations. For the generalizability of these results it will be important to bear in mind that the scales used in this study to measure masculinity/femininity have proved their worth in different countries/cultures (in AsianAmerican, Italian-American and Anglo-American people in the USA, Spanish, Australian and Nigerian populations).

\section{References}

Addis, M., \& Mahalik, J. R. (2003). Men, masculinity, and the contexts of help seeking. The American Psychologist, 58(1), 5-14. doi:10.1037/0003-066x.58.1.5

Al-Dubai, S. A., \& Rampal, K. G. (2010). Prevalence and associated factors of burnout among doctors in Yemen. Journal of Occupational Health, 52(1), 58-65. doi:10.1539/joh.O8030

Auster, C. J., \& Ohm, S. C. (2000). Masculinity and femininity in contemporary American society: A reevaluation using the Bem Sex-Role Inventory. Sex Roles, 43(7/8), 499-528. doi:10.1023/a:1007119516728
Battice, J. (2010). The changing face of nursing in a developing country. Journal of Clinical Nursing, 19(13/14), 1765-1766. doi:10.1111/j.1365-2702.2009.02882.

Bonet-Porqueras, R., Molineé-Pallarés, A., Olona-Cabases, M., Gil-Mateu, E., Bonet-Notario, P., Les-Morrell, E., ... Bonet-Porqueras, M. (2009). Turno nocturno: Un factor de riesgo en la salud y calidad de vida del personal de enfermería [The night shift: A risk factor for health and quality of life in nursing staff]. Enfermería Clinica, 19(2), 76-82. doi:10.1016/j.enfcli.2008.10.010

Conry, M. C., Morgan, K., Curry, P., McGee, H., Harrington, J., Ward, M., \& Shelley, M. (2011). The clustering of health behaviours in Ireland and their relationship with mental health, selfrated health and quality of life. $B M C$ Public Health, 11, 692. doi:10.1186/1471-2458-11-692

Cuéllar-Flores, I., \& Dresch, V. (2012). Validación del cuestionario de Apoyo Social Funcional Duke-UNK-11 en personas cuidadoras [Validation of the Duke-UNK-11 functional social support questionnaire in caregivers]. Revista Iberoamericana de Diagnóstico y Evaluación e Avaliação Psicológica, 2(34), 89-101. Retrieved from http://www.aidep.org/03_ridep/R34/ART\%204.pdf

Cuéllar-Flores, I., \& Sánchez-López, M. P. (2011). Masculinity: How it can be made operative and its use in health. In M. E. Harrison \& P. W. Schnarrs (Eds.), Beyond borders: Masculinities and margins: The 17th Annual American Men's Studies Association Conference Proceedings (pp. 160-180). Harriman, TN: Men's Studies Press.

Cuéllar-Flores, I., Sánchez-López, M. P., \& Dresch, V. (2011). El Inventario de Conformidad con las Normas de Género Masculinas (CMNI) en la población española [Conformity to Masculine Gender Norms Inventory in the Spanish population]. Anales de Psicología, 27(1), 170-178. Retrieved from http://www.redalyc.org/articulo.oa?id=16717018020

Deschamps Perdomo, A., Olivares Román, S. B., De la Rosa Zabala, K. L., \& Asunsolo del Barco, A. (2011). Influencia de los turnos de trabajo y las guardias nocturnas en la aparición del Síndrome de burnout en médicos y enfermeras [Influence of shift work and night shifts in the onset of the Burnout Syndrome in doctors and nurses]. Medicina y Seguridad del Trabajo, 57(224), 224-241. doi:10.4321/S0465-546X2011000300004

Fisher, M. J. (2011). Sex differences in gender characteristics of Australian nurses and male engineers: A comparative cross-sectional survey. Contemporary Nurse: A Journal for the Australian Nursing Profession, 39(1), 36-50. doi:10.5172/conu.2011.39.1.36

Instituto Nacional de Estadística. (2012). Estadística de profesionales sanitarios colegiados [Survey of the number of health professionals registered in Spain]. Retrieved from http://www.ine.es/dynt3/ inebase $/$ es $/$ index.$h t m ?$ type $=$ pcaxis $\&$ file $=$ pcaxis $\&$ path $=\% 2 \mathrm{Ft} 15 \% 2 \mathrm{Fp} 416 \% 2 \mathrm{~F} \% 2 \mathrm{Fa} 2012$ 
Instituto de Salud Carlos III. (2011). RN4CAST: Informe sobre la encuesta de enfermeras: Informe Global de los hospitales españoles. Madrid, España: Autor. Retrieved from http://enfermeriacomunitaria.org/web/attachments/ article/322/Informe $\% 20$ RN4CAST $\% 20$ hospitales $\% 20$ espan $\%$ CC $\% 83$ oles.pdf

Izú, M., Cortez, E. A., Valente, G. C., \& Silvino, Z. R. (2011). Trabalho noturno como fator de risco na carcinogênese [Night work as a risk factor in carcinogenesis]. Ciencia y Enfermeria, 17(3), 83-95. doi:10.4067/s0717-95532011000300008

Lee, W.-L., Tsai, S.-H., Tsai, C.-W., \& Lee, C.-Y. (2011). A study on work stress, stress coping strategies and health promoting lifestyle among district hospital nurses in Taiwan. Journal of Occupational Health, 53(5), 377-383. doi:10.1539/joh.11-0054-FS

Limiñana-Gras, R. M., Sánchez-López, M. P., Saavedra-San Román, A. I., \& Corbalán-Berná, J. F. (2013). Health and gender in female dominated occupations: The case of male nurses. The Journal of Men's Studies, 21(2), 135-148. doi:10.3149/jms.2102.135

Loughrey, M. (2008). Just how male are male nurses? Journal of Clinical Nursing, 17(10), 1327-1334. doi: 10.1111/j.1365-2702.2007.02250.x

Lupton, B. (2000). Maintaining masculinity: Men who do women's work. British Journal of Management, 11(1), 33-48. doi:10.1111/1467-8551.11.s1.4

Mahalik, J. R., \& Burns, S. M. (2011). Predicting health behaviors in young men that put them at risk for heart disease. Psychology of Men \& Masculinity, 12(1), 1-12. doi:10.1037/a0021416

Mahalik, J. R., Burns, S. M., \& Syzdek, M. (2007). Masculinity and perceived normative health behaviors as predictors of men's health behaviors. Social Science \& Medicine, 64(11), 2201-2209. doi: 10.1016/j.socscimed.2007.02.035

Mahalik, J. R., Lagan, H. D., \& Morrison, J. A. (2006). Health behaviors and masculinity in Kenyan and U.S. male college students. Psychology of Men \& Masculinity, 7(4), 191-202. doi:10.1037/1524-9220.7.4.191

Mahalik, J. R., Locke, B. D., Ludlow, L. H., Diemer, M. A., Scott, R. P. J., Gottfried, M., \& Freitas, G. (2003). Development of the Conformity to Masculine Norms Inventory. Psychology of Men \& Masculinity, 4(1), 3-25. doi:10.1037/1524-9220.4.1.3

Mahalik, J. R., Morray, E. B., Coonerty-Femiano, A., Ludlow, L. H., Slattery, S. M., \& Smiler, A. (2005). Development of the Conformity to Feminine Norms Inventory. Sex Roles, 52(7/8), 417-435. doi:10.1007/s11199-005-3709-7
Mao, Z.-H., \& Zhao, X.-D. (2012). The effects of social connections on self-rated physical and mental health among internal migrant and local adolescents in Shanghai, China. BMC Public Health, 12, 97. doi:10.1186/1471-2458-12-97

Sánchez-Herrero Arbide, S. A., Sánchez-López, M. P., \& Dresch, V. (2009). Hombres y trabajo doméstico: Variables demográficas, salud y satisfacción [Men and housework: Demographic variables, health, and satisfaction]. Anales de Psicología, 25(2), 299-307. Retrieved from http://www.um.es/analesps/v25/v25_2/12-25_2.pdf

Sánchez-López, M. P., Aparicio García, M. E., \& Dresch, V. (2006). Ansiedad, autoestima y satisfacción autopercibida como predictores la salud: Diferencias entre hombres y mujeres [Anxiety, self-esteem, and self-perceived satisfaction as predictors of health: Differences between men and women]. Psicothema, 18(3), 584-590. Retrieved from http://www.psicothema.com/pdf/3257.pdf

Sánchez-López, M. P., Cuellar-Flores, I., \& Dresch, V. (2012). The impact of gender roles on health. Women \& Health, 52(2), 182-196. doi:10.1080/03630242.2011.652352

Sánchez-López, M. P., Cuellar-Flores, I., Dresch, V., \& Aparicio García, M. (2009). Conformity to feminine gender norms in the Spanish population. Social Behavior and Personality, 37(9), 1171-1185. doi:10.2224/sbp.2009.37.9.1171

Sánchez-López, M. P., López-García, J. J., Dresch, V., \& Corbalán, J. (2008). Sociodemographic, psychological and health-related factors associated with poor mental health in Spanish women and men in midlife. Women \& Health, 48(4), 445-465. doi:10.1080/03630240802575096

Simon, J. G., De Boer, J. B., Joung, I. M., \& Mackenbach, J. P. (2005). How is your health in general? A qualitative study on self-assessed health. European Journal of Public Health, 15(2), 200-208. doi:10.1093/eurpub/cki102

Simpson, R. (2009). Men in caring occupations: Doing gender differently. New York, NY: Palgrave Macmillan.

Sindicato de Enfermería. (2012). Percepción de estrés en los profesionales de Enfermería en España. Madrid, España: Estudio SATSE. Retrieved from http://www.easp.es/ crisis-salud/busqueda/resultados/item/1038-percepcionde-estres-en-los-profesionales-de-enfermeria-en-espanapercepcion-y-sintomas-de-estres-en-el-colectivoenfermero-espanol

Talley, G., Thomas, R. E., \& Brown, K. C. (2009). A health comparison of Alabama nurses versus US, UK and Canadian normative populations. Journal of Orthopaedic Nursing, 13(4), 172-182. doi:10.1016/j.joon.2009.03.005

World Health Organization. (2007). En qué consiste el enfoque de salud pública basado en el género [What is a gender-based approach to public health?] Retrieved from http://www.who.int/features/qa/56/es/ 
Virginia Dresch is a Professor of the Universidade Federal Fluminense, Niteroi-RJ, Brazil.

María del Pilar Sánchez-López is a Professor of the Universidad Complutense de Madrid, Madrid, Espanha.

Ana Isabel Saavedra is a nurse of the Hospital Universitario de Getafe.

Authors' Contribution:

All authors made substantial contributions to the conception and design of this study, to data analysis and interpretation, and to the manuscript revision and approval of the final version. All the authors assume public responsability for content of the manuscript.

Received: Mar. 03, 2015

1st Revision: Mar. 03, 2016

Approved: Oct. 11, 2016

How to cite this article:

Dresch, V., Sanchez-Lopez, M. P. \& Saavedra, A. I. (2018).

Gender and health in spanish nurses. Paidéia (Ribeirão Preto), 28, e2829. doi: http://dx.doi.org/10.1590/1982-4327e2829 